\section{Survival analysis of women with cervical cancer treated at a referral hospital for oncology in Espírito Santo State, Brazil, 2000-2005}

\author{
Análise da sobrevida de mulheres com câncer do \\ colo do útero atendidas em hospital de referência \\ para oncologia no Espírito Santo, Brasil, nos anos \\ de 2000 a 2005
}
Análisis de la supervivencia de mujeres con cáncer de cuello de útero atendidas en un hospital oncológico de referencia en Espírito Santo, Brasil, desde 2000 a 2005

Keila Cristina Mascarello 1 Eliana Zandonade 2 Maria Helena Costa Amorim 2

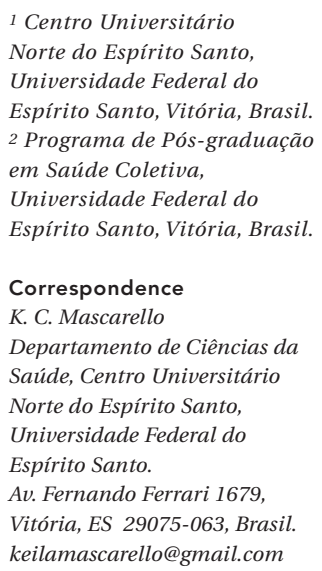

\begin{abstract}
Uterine cervical cancer is a leading cause of death from cancer in the female population worldwide. The aim of this study was to analyze survival of women with cervical cancer treated at the Santa Rita de Cássia Hospital/Women's Association for Cancer Education and Control (HSRC/AFECC) in Espírito Santo State, Brazil, from 2000 to 2005 and to describe associated prognostic factors. This was a cohort study using retrospective secondary data with a sample of 964 cases. The Kaplan-Meier curve and Cox model were used to evaluate survival and for multiple logistic analysis. There were 421 deaths (43.6\%) during the minimum 5-year follow-up, with an overall 5 -year survival of 58.8\%. Risk factors were place of residence in the Serrana Region of the State (HR: 1.94; 95\%CI: 1.09-3.45) and advanced staging. Women with stages III and IV at diagnosis showed an increased risk of 4.33 (95\%CI: 3.006.24) and 15.40 (95\%CI: 9.72-24.39), respectively, for lower survival when compared to stage I. The results show that early diagnosis and treatment are essential for reducing mortality from cervical cancer.
\end{abstract}

Uterine Cervical Neoplasms; Women's Health; Survival Analysis

\section{Resumo}

O câncer do colo do útero corresponde a uma das principais causas de morte por neoplasias na população feminina mundial. O objetivo deste estudo foi analisar a sobrevida de mulheres com câncer do colo do útero atendidas no Hospital Santa Rita de Cássia/Associação Feminina de Educação e Combate ao Câncer (HSRC/AFECC) durante o período de 2000 a 2005 e descrever os fatores prognósticos associados. Trata-se de um estudo de coorte com utilização de dados secundários retrospectivos, com amostra de 964 casos. Foram utilizados a curva de Kaplan-Meier e o modelo de Cox para avaliação da sobrevida e para análise logística múltipla. Ocorreram 421 (43,6\%) óbitos no período mínimo de 5 anos de seguimento, com sobrevida global de $58,8 \%$ em 5 anos. Identificaram-se como risco a procedência Região Serrana (1,94 vez, IC95\%: 1,09-3,45) e estadiamento crescente. As mulheres com estadiamento III e IV apresentaram risco de 4,33 (IC95\%: 3,00-6,24) e 15,40 (IC95\%: 9,72-24,39) vezes maior, respectivamente, de terem menor sobrevida quando comparadas ao estádio I. Os resultados demonstram que o diagnóstico e tratamento precoces são fundamentais na redução da mortalidade por câncer do colo do útero.

Neoplasias do Colo do Útero; Saúde da Mulher; Análise de Sobrevida 


\section{Introduction}

Uterine cervical cancer is one of the leading causes of death from cancer in the female population worldwide, especially in the less developed regions, where $83 \%$ of all cervical cancer incidence and $86 \%$ of mortality occur 1 . In the year 2015 , some 320,000 new cases are expected in the world, increasing to 435,000 by 20302 .

Brazil is expected to have 17,540 new cases of cervical cancer in 2012, or approximately 17 cases per 100,000 women. Not including nonmelanoma skin tumors, in 2012 cervical cancer was estimated to have the highest incidence rates in the North of Brazil $(24 / 10,000)$, ranking second in the Central West $(28 / 100,000)$ and Northeast $(18 / 100,000)$ and third and fourth in the Southeast $(15 / 100,000)$ and South $(14 / 100,000)$, respectively ${ }^{3}$. According to the Brazilian National Cancer Institute (INCA), in 2012 some 340 new cases were estimated for the State of Espírito Santo, representing an incidence rate of 18.65 cases per 100,000 women 3 .

Survival analysis provides important information for epidemiological surveillance of cancer, because its measurement helps explain the importance of staging of the disease and treatment access and effectiveness ${ }^{2}$, using statistical methods to estimate the influence of covariates with survival time, or time since initial observation of the patient until the occurrence of a target event. In survival analysis, the most important parameters are probability of survival in each of the target intervals and accumulated survival probability (survival rate), i.e., the probability of surviving from time zero until the final target date 4

The principal prognostic and survival factor for uterine cervical cancer is initial staging 5,6,7,8 Thus, late diagnosis is one of the main factors accounting for persistently high mortality rates 4 and shorter survival.

In addition to staging at diagnosis, other factors are associated with survival of women with cervical cancer, including socioeconomic status 1,5 , age at diagnosis 1 , histological tumor type 9 , and skin color (race) 5 .

The aim of the current study was to analyze the survival of women with cervical cancer treated at the Santa Rita de Cássia Hospital/Women's Association for Cancer Education and Control (HSRC/AFECC) from 2000 to 2005 and describe associated prognostic factors.

\section{Methodology}

This was a cohort survival study using retrospective secondary data. The sample consisted of women with cervical cancer treated at the HSRC/ AFECC from January 1, 2000, to December 31, 2005.

In compliance with Ruling n. 741 of December 19, 2005, the study data were collected from May to September 2011 at the Hospital Cancer Registry of the HSRC/AFECC, a private and charitable hospital, and the Center for High-Complexity Cancer Care (CACON), located in Vitória, capital of Espírito Santo State, Brazil.

Data were collected from the Tumor Registry Forms as well as from patient charts for data that were missing on the forms. To consult patient charts, a specific instrument was developed containing the following variables: treatment history, relapses, metastases, initial staging, date of death, and underlying cause of death.

The inclusion criteria were: women without prior treatment, with or without prior diagnosis. The exclusion criteria were: women with diagnosis of in situ neoplasm, diagnosis of relapse, those who had initiated treatment in another institution, or those who lived in other States of Brazil, due to the difficulty in verifying outcome for these women.

Nine variables (including clinical and sociodemographic variables) were analyzed. Clinical variables were histological type (squamous cell carcinoma versus others) and staging (I, II, III, and IV). Socio-demographic variables were age bracket (up to 49 years and 50 years or older); race/color, not self-reported (white versus nonwhite); schooling (primary or less versus secondary and university); marital status (married, single, separated/divorced, widow); origin of referral (National Health System versus not National Health System), and region of residence within Espírito Santo State (North, South, Serrana, or Greater Metropolitan Vitória).

Deaths were verified by a manual search in the databank of the Mortality Information System (SIM) for the years 2000 to 2010, provided by the State Health Secretariat, which covers deaths recorded in the State of Espírito Santo. For crosschecking between the current study's databank and the Mortality Information System, the parameters used were patient's name and date of birth and mother's name. Causes of death were classified according to the 10th Revision of the International Classification of Diseases (ICD10) and those attributed to cervical cancer were situations in which the underlying cause of death was specified as C53 and its derivations C53.0, C53.1, C53.8, C53.9, and C55.9 (malignant neo- 
plasm of cervix uteri, not otherwise specified) and the ICD-10 of the metastasis when the latter was present and was certified as the underlying cause of death.

Survival time was calculated in months, considering date of diagnosis as the initial date for all patients. For patients whose underlying cause of death was neoplasm of the uterine cervix, identified as the target event (failure), the final date was date of death, obtained from the SIM. Deaths from other causes were also censored and the date of censor was the date of death recorded in the SIM. Finally, for patients that did not die (censored), the final date was defined as December 31, 2010. Patients not found in the SIM were considered alive on that date. This date was used, since $51 \%$ of the patients did not have the minimum followup of five years recorded on their patient chart. Maximum follow-up time was 10 years.

Survival analysis was performed with the Kaplan-Meier method, with the aim of determining mean survival time for cervical cancer. Kaplan-Meier curves were calculated for the categories of study variables. The log-rank method was used to compare the accumulated survival curves between the different categories of study variables. The Cox proportional risks multivariate model was used (hazard ratio - HR) aimed at verifying the independent effect of the study variables that presented statistical significance up to $10 \%$ in the log-rank test. Statistical analysis used SPSS version 18.0 (SPSS Inc., Chicago, USA). Significance in the final model was set at 5\%. Stata version 11.0 (Stata Corp., College Station, USA) was used to calculate the Cox regression power, considering the study's final sample (964 women) and a minimum HR of 1.2. The calculated power was $80 \%$.

The study complied with Ruling n. 196/96 of the Brazilian National Health Council and its complementary provisions, and was approved by the Institutional Review Board of the Center for Health Sciences at the Federal University in Espírito Santo, case number 218/10.

\section{Results}

From 2000 to 2005, 1,266 women were treated for invasive cervical cancer at the HSRC/AFECC, but the study excluded 65 (5.1\%) whose staging was missing on their patient charts, 191 (15.08\%) who had been referred to the institution after initiating therapy, and 46 (3.6\%) who were from other States of Brazil. The final sample consisted of 964 women.

At the time of diagnosis, mean age was 53.8 years, standard deviation (SD) 14.1, and median age 53 years. The women were predominantly in the $40-59$-year age bracket $(49.3 \%)$, non-white (76.8\%), with incomplete primary schooling or less $(70.9 \%)$, married $(48.3 \%)$, referred through the National Health System (84.2\%), and living in Greater Metropolitan Vitória (59.6\%). Predominant histological type was squamous cell carcinoma (87\%). Initial staging was III in $44 \%$, followed by II in $31.4 \%$. The majority of the patients $(52.1 \%)$ had only received radiotherapy, 133 presented local relapse (28.2\%), 218 (43.4\%) had distant metastases, and 27 (2.8\%) had more than one primary tumor.

Among the 964 women, there were 421 deaths (43.6\%) from cervical cancer with a minimum of five and maximum of ten years of follow-up. There were also 87 deaths (9\%) from other causes, considered censored data in the survival study. The percentage of deaths from cervical cancer at five years was $58.8 \%$, and the Kaplan-Meier 5 -year survival estimate was $57.4 \%$. Mean survival time in the study period was 82.6 months. Figure 1 shows the accumulated survival for the women in the study, calculated by the KaplanMeier method.

Table 1 shows the socio-demographic and clinic variables with the unadjusted survival functions. The variables age bracket, race/color, and schooling did not show any significant difference in survival. There were significant differences according to region of residence and initial staging, showing that women with early diagnosis present longer survival time.

Five-year survival was $85 \%$ for stage I, $64.3 \%$ for stage II, $48.6 \%$ for stage III, and only $14 \%$ for stage IV.

Table 2 shows that crude HR points to greater risk of lower survival associated with residence in Greater Metropolitan Vitória (1.31 times). Advanced staging showed an increased risk of disease progression.

The multivariate model, in which all variables were adjusted in the same model, identified as risk factors place of residence in the Serrana Region of Espírito Santo State (1.94 times) and staging. Women with stages III and IV showed an increased risk of 4.33 and 15.40, respectively, of shorter survival.

Figure 2 shows the accumulated survival curves, calculated by the Kaplan-Meier method, according to the women's region of residence. Figure 3 provides the stratified survival curves according to initial staging. 
Survival curve for women with uterine cervical cancer treated at the Santa Rita de Cássia Hospital, Vitória, Espírito Santo State, Brazil. January 1, 2000, to December 31, 2005.

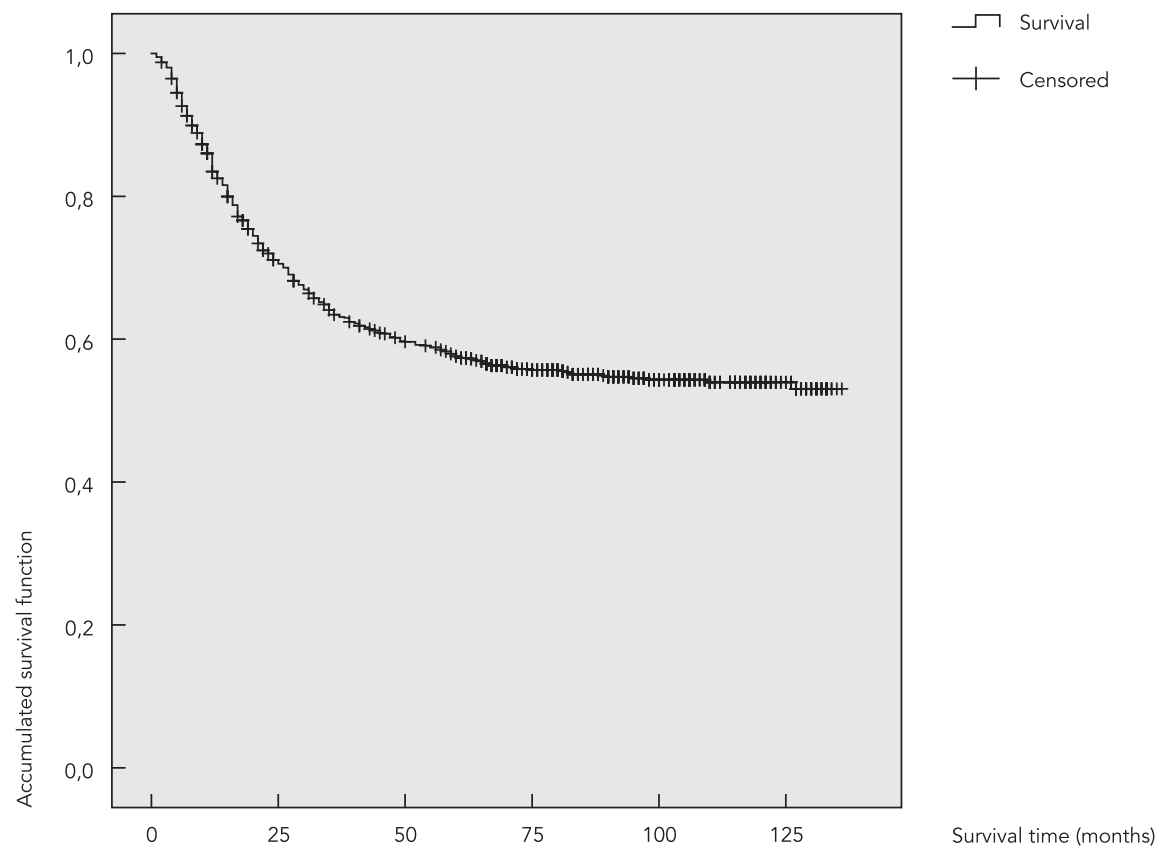

\section{Discussion}

Few Brazilian studies have analyzed the survival of women with cervical cancer. A study in Rio de Janeiro with 3,341 women found $48 \%$ overall fiveyear survival 5 , considering all deaths and not only those attributed to cervical cancer, which can lead to underestimation of survival from uterine cervical cancer, since all deaths were considered target events. A study in Paraná State in Southern Brazil reported $53.6 \%$ overall five-year survival in a total of 2,396 cases 10 , a lower percentage than in our study, which was $58.8 \%$ at five years. A study in Colombia also showed $58.8 \%$ overall five-year survival 6 , while a study in Chile showed $46.3 \%$ five-year survival 7 .

According to the American Cancer Society overall five-year survival for cervical cancer is $72 \%$ in the United States 11. According to one study, estimated mean overall five-year survival in developed countries ranges from $59 \%$ to $69 \%$. Meanwhile, in the developing countries, were diagnosis is performed at relatively advanced stages, mean five-year survival is estimated at only $49 \% 12$.
In the current study, the most common initial stage was III, representing $44 \%$ of patients. According to a study in 96 cancer treatment institutions in Brazil, although many women still reach treatment centers with cervical cancer in advanced stages, the number has decreased in recent years, but is still far from reaching the levels observed in developed countries 13. In England, $23.8 \%$ of 382 women were diagnosed in stages III and IV 14. Another study in the United States found only $7 \%$ of advanced cases with distant metastases 15 . This lower proportion of initial diagnosis in advanced stages contributes to the longer survival observed in these countries 11 . The high percentage of advanced staging can be considered a determinant factor in the high rate of metastases and local relapses observed in the current study, further contributing to the maintenance of high mortality rates observed in the State of Espírito Santo, since only early diagnosis can intervene in morbidity and mortality from uterine cervical cancer.

Women with low schooling have an increased risk of developing cervical cancer 16,17. Lower education is associated with higher risk of diagnosis 
Table 1

Number of deaths, mean survival time, and 95\% confidence lower limits (LL) and upper limits (UL) estimated by the Kaplan-Meier method and result of log-rank test ( $\mathrm{p}$-value) for the study variables in a sample of women with cervical cancer, Espírito Santo State, Brazil.

\begin{tabular}{|c|c|c|c|c|c|c|}
\hline \multirow[t]{2}{*}{ Variable/Category } & \multirow[t]{2}{*}{$\mathrm{n}$} & \multirow[t]{2}{*}{ Deaths } & \multicolumn{3}{|c|}{ Mean survival time (months) } & \multirow{2}{*}{$\begin{array}{c}\text { Log-rank } \\
\text { p-value }\end{array}$} \\
\hline & & & Mean & 95\%LL & $95 \%$ UL & \\
\hline \multicolumn{7}{|l|}{ Age bracket (years) } \\
\hline$\leq 49$ & 403 & 167 & 85.1 & 79.5 & 90.7 & 0.221 \\
\hline$\geq 50$ & 561 & 254 & 80.3 & 75.6 & 85.0 & \\
\hline \multicolumn{7}{|l|}{ Race/Color } \\
\hline White & 220 & 103 & 77.9 & 70.4 & 85.4 & 0.360 \\
\hline Non-white & 730 & 314 & 83.3 & 79.1 & 87.4 & \\
\hline \multicolumn{7}{|l|}{ Schooling } \\
\hline$\leq$ Primary & 403 & 167 & 83.0 & 79.2 & 86.9 & 0.878 \\
\hline Secondary and/or university & 561 & 254 & 81.0 & 67.2 & 94.9 & \\
\hline \multicolumn{7}{|l|}{ Marital status } \\
\hline Married & 465 & 194 & 84.4 & 79.2 & 89.7 & 0.669 \\
\hline Single & 221 & 102 & 79.8 & 72.4 & 87.2 & \\
\hline Separated/Divorced & 61 & 25 & 87.4 & 74.0 & 100.8 & \\
\hline Widow & 214 & 97 & 79.8 & 72.1 & 87.5 & \\
\hline \multicolumn{7}{|l|}{ Region of Residence in State } \\
\hline North & 302 & 113 & 88.6 & 82.3 & 94.9 & 0.044 \\
\hline South & 64 & 24 & 86.7 & 72.8 & 100.7 & \\
\hline Serrana (Mountainous Region) & 23 & 13 & 60.3 & 41.2 & 79.3 & \\
\hline Greater Metropolitan Vitória & 575 & 271 & 79.3 & 74.7 & 84.0 & \\
\hline \multicolumn{7}{|l|}{ Origin of referral } \\
\hline Brazilian Unified National Health System (SUS) & 738 & 329 & 81.8 & 77.7 & 86.0 & 0.875 \\
\hline Non-SUS & 136 & 60 & 82.0 & 72.5 & 91.5 & \\
\hline \multicolumn{7}{|l|}{ Histological type } \\
\hline Squamous cell carcinoma & 839 & 369 & 82.4 & 78.6 & 86.3 & 0.775 \\
\hline Other & 125 & 52 & 79.8 & 70.4 & 89.3 & \\
\hline \multicolumn{7}{|l|}{ Prior diagnosis } \\
\hline Yes & 180 & 85 & 77.3 & 69.0 & 85.6 & 0.311 \\
\hline No & 784 & 336 & 83.6 & 79.6 & 87.7 & \\
\hline \multicolumn{7}{|l|}{ Staging } \\
\hline I & 187 & 33 & 114.7 & 108.9 & 120.5 & 0.001 \\
\hline II & 303 & 118 & 88.7 & 82.7 & 94.7 & \\
\hline III & 424 & 227 & 69.1 & 63.6 & 74.6 & \\
\hline IV & 50 & 43 & 23.7 & 13.4 & 33.9 & \\
\hline
\end{tabular}

in advanced stages in these tumors 18 . However, unlike survival studies for other types of cancer 19,20,21,22, the variables race/color and schooling were not significantly associated with survival time. Another Brazilian study also failed to find a statistically significant difference in survival time among women with cervical cancer according to race/color 5 . This result can be attributed to this study sample's homogeneity in relation to race/ color and schooling.
In the analysis with crude $\mathrm{HR}$, the variables place of residence in Greater Metropolitan Vitória and advanced staging showed worse prognosis, but in the multivariate analysis the variables place of residence in the Serrana Region or Greater Metropolitan Vitória and advanced staging were associated with shorter survival time. As for place of residence, the lack of studies on Pap smear coverage in the State does not allow concluding whether the shorter survival in the Serrana Region and Greater Vitória is related to lower 
Table 2

Hazard ratio (HR). crude and adjusted by the Cox model, with the respective lower and upper $95 \%$ confidence limits (LL and UL) for statistically significant variables in the log-rank tests in a sample of women with cervical cancer, Espírito Santo State, Brazil.

\begin{tabular}{|c|c|c|c|c|c|c|c|c|}
\hline \multirow[t]{2}{*}{ Variable/Category } & \multicolumn{4}{|c|}{ Crude HR } & \multicolumn{4}{|c|}{ Cox adjusted HR } \\
\hline & $p$-value & Estimate & $95 \%$ LL & $95 \%$ UL & p-value & Estimate & $95 \%$ LL & $95 \%$ UL \\
\hline \multicolumn{9}{|l|}{ Region of residence in State } \\
\hline North & & 1,00 & & & & 1,00 & & \\
\hline South & 0,903 & 1,03 & 0,66 & 1,60 & 0,399 & 1,21 & 0,78 & 1,89 \\
\hline Serrana (Mountainous Region) & 0,078 & 1,67 & 0,94 & 2,97 & 0,024 & 1,94 & 1,09 & 3,45 \\
\hline Greater Metropolitan Vitória & 0,015 & 1,31 & 1,05 & 1,64 & 0,002 & 1,42 & 1,13 & 1,77 \\
\hline \multicolumn{9}{|l|}{ Staging } \\
\hline I & & 1,00 & & & & 1,00 & & \\
\hline ॥ & 0,001 & 2,56 & 1,74 & 3,77 & 0,001 & 2,52 & 1,71 & 3,70 \\
\hline III & 0,001 & 4,35 & 3,01 & 6,26 & 0,001 & 4,33 & 3,00 & 6,24 \\
\hline IV & 0,001 & 14,38 & 9,10 & 22,71 & 0,001 & 15,40 & 9,72 & 24,39 \\
\hline
\end{tabular}

\section{Figure 2}

Survival curve stratified by region of residence for women with uterine cervical cancer treated at the Santa Rita de Cássia Hospital, Vitória, Espírito Santo State, Brazil. January 1, 2000, to December 31, 2005.

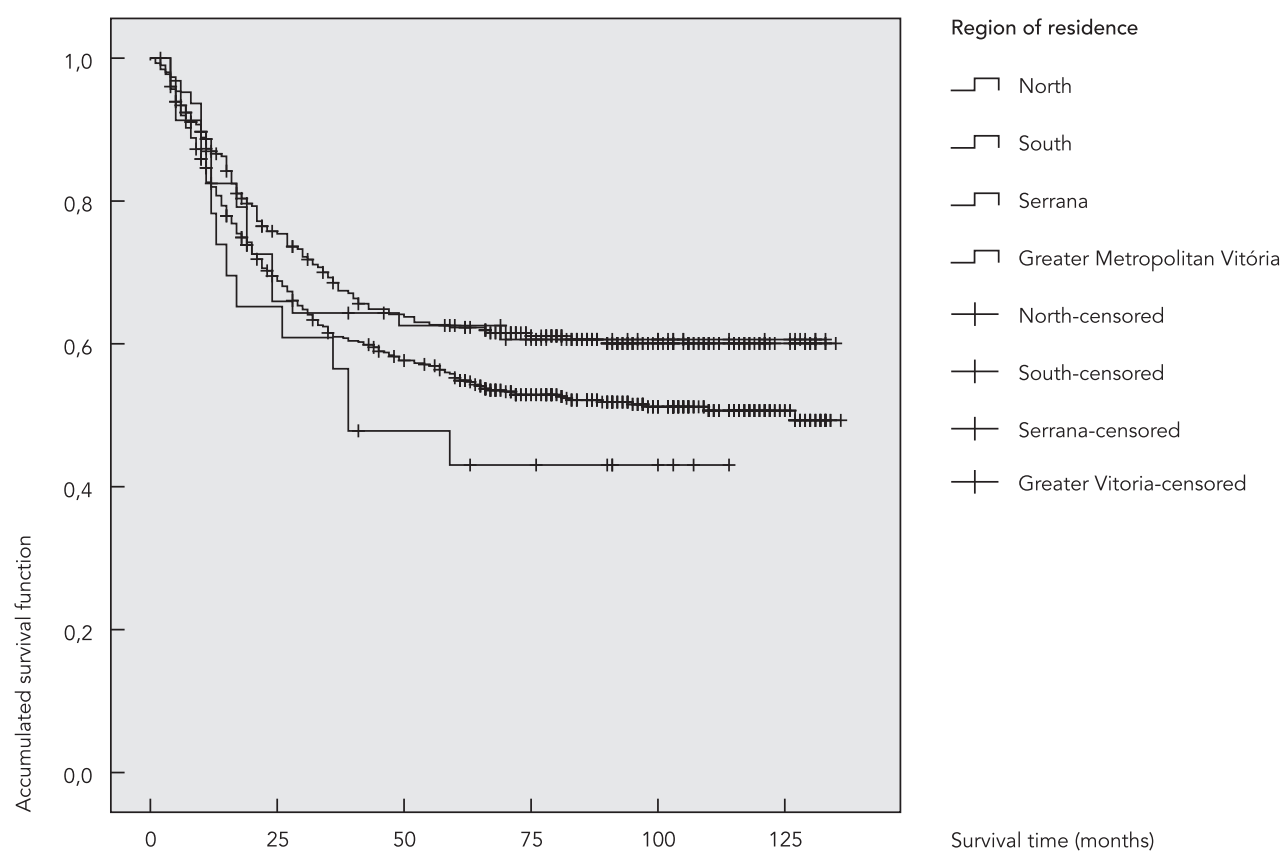


Survival curve stratified by cervical cancer staging in women treated at the Santa Rita de Cassia Hospital, Vitória, Espírito Santo State, Brazil. January 1, 2000, to December 31, 2005.

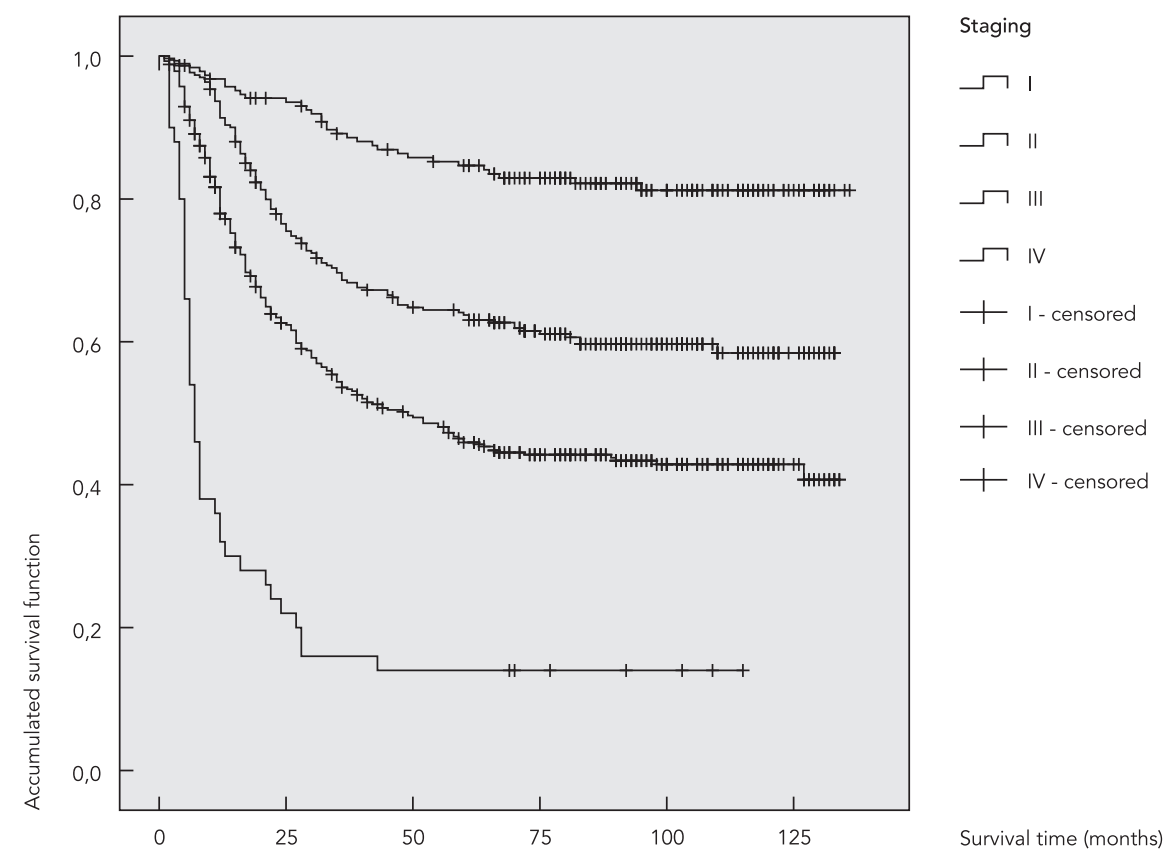

Pap smear coverage. In addition, on the registration form at the referral hospital, women from other regions of the State may have informed the address where they were located at the time of treatment rather than their normal place of residence, thus leading to underestimation of survival in Greater Metropolitan Vitória.

Staging consists of tumor classification according to its clinical characteristics and is an important means for defining patient prognosis and therapy 8. A survival analysis study in Chile showed $78 \%$ five-year survival for stage I, $60 \%$ for stage II, and $29 \%$ for stage III, with $100 \%$ fiveyear mortality in stage IV (with the presence of distant metastases) ${ }^{7}$, thus demonstrating that survival is directly related to tumor stage at diagnosis. In addition, staging is a predictor of cancer outcome and is directly related to presence of metastases. Other authors have shown the same relationship 5,6.

\section{Conclusion}

The current study shows that shorter survival in cervical cancer is associated with place of residence and initial staging, directly related to timely access to health services for diagnosis and treatment and thus amenable to intervention measures.

The survival time observed here shows that the challenge is still to reach similar levels to those of developed countries. It is hoped that effective implementation of women's health programs and primary care policies will be capable of guaranteeing women's timely access to health services, thereby increasing the possibilities for recovery and cure. Since cervical cancer has a long pre-clinical phase, measures to actively search for women at risk, such as those who have not performed a Pap smear for more than three years, should be established in primary health care services, aimed at diagnosis in the early stages of the disease, when treatment is less aggressive and involves lower cost.

It should be noted that this study was conducted in a single institution for cancer diagnosis 
and treatment in the city of Vitória. In addition $5.1 \%$ of cases were excluded from the sample due to lack of data on staging. Another limitation to the study was the lack of active search for women and the fact that those not located in the Mortality Information System were considered alive at the study's closing date, since flaws in records or occurrence of deaths in other States may have led to an underestimation of survival, even though the probability is low, since the system is considered quite reliable.

Given the magnitude of cervical cancer incidence, other studies are needed to evaluate survival of women with uterine cervical cancer, providing further support for public policy planning and control of the disease.

\section{Resumen}

El cáncer de cuello de útero corresponde a una de las principales causas de muerte por neoplasias en la población femenina mundial. El objetivo de este estudio fue analizar la supervivencia de mujeres con cáncer de cuello de útero, atendidas en el Hospital Santa Rita de Cássia/Asociación Femenina de Educación y Combate al Cáncer (HSRC/AFECC), durante el período de 2000 a 2005 y describir los factores pronósticos asociados. Se trata de un estudio de cohorte con utilización de datos secundarios retrospectivos, con una muestra de $964 \mathrm{ca}$ sos. Se utilizaron la curva de Kaplan-Meier y el modelo de Cox para la evaluación de la supervivencia y para el análisis logístico múltiple. Se produjeron 421 (43,6\%) óbitos durante un período mínimo de 5 años de seguimiento, con una sobrevida global de 58,8\% en 5 años. Se identificó como un riesgo la procedencia de Región Serrana (1,94 veces, IC95\%: 1,09-3,45) e internamientos hospitalarios crecientes. Las mujeres con internamien tos hospitalarios III y IV presentaron un riesgo de 4,33 (IC95\%: 3,00-6,24) y 15,40 (IC95\%: 9,72-24,39) veces mayor, respectivamente, de tener menor supervivencia cuando se comparaban al estadio I. Los resultados de muestran que el diagnóstico y tratamiento precoces son fundamentales en la reducción de la mortalidad por cáncer de cuello de útero.

Neoplasias del Cuello Uterino; Salud de la Mujer; Análisis de Supervivencia

\section{Contributors}

K. C. Mascarello, E. Zandonade, and M. H. C. Amorim participated in the research project design and plan ning, obtaining and interpreting the data, and writing and critical revision of the article. 


\section{References}

1. Parkin DM, Whelan SL, Ferlay J, Teppo L, Thomas DB, editors. Cancer incidence in five continents. Lyon: IARC Press; 2005.

2. International Agency for Research on Cancer; World Health Organization. World Cancer Report, 2008. Lyon: IARC Press; 2008.

3. Instituto Nacional de Câncer. Estimativa 2012: incidência de câncer no Brasil. Rio de Janeiro: Instituto Nacional de Câncer; 2011.

4. Bustamante-Teixeira MT, Faerstein E, Latorre MR. Técnicas de análise de sobrevida. Cad Saúde Pública 2002; 18:579-94.

5. Carmo CC, Luiz RR. Survival of a cohort of women with cervical cancer diagnosed in a Brazilian cancer center. Rev Saúde Pública 2011; 45:661-7.

6. Pardo C, Cendales R. Supervivencia de pacientes con cáncer de cuello uterino tratadas en el Instituto Nacional de Cancerología. Biomédica (Bogotá) 2009; 29:437-47.

7. Sepúlveda PV, González FC, Napolitano CR, Roncone ED, Cavada GC. Cáncer de cuello uterino: sobrevida a 3 y 5 años en hospital San José. Rev Chil Obstet Ginecol 2008; 73:151-4.

8. Instituto Nacional de Câncer. TNM: classificação de tumores malignos. Rio de Janeiro: Instituto Nacional de Câncer; 2004.

9. Coker A, Du X, Fang S, Eggleston K. Socioeconomic status and cervical cancer survival among older women: findings from the SEER-Medicare linked data cohorts. Gynecol Oncol 2006; 102:278-84.

10. Liga Paranaense de Combate ao Câncer. Relatório epidemiológico: RHC 2000 a 2004. Curitiba: Hospital Erasto Gaertner; 2007.

11. American Cancer Society. Cancer facts and figures. Atlanta: American Cancer Society; 1999.

12. Instituto Nacional de Câncer. Nomenclatura brasileira para laudos cervicais e condutas preconizadas: recomendações para profissionais de saúde. Rio de Janeiro: Instituto Nacional de Câncer; 2006.

13. Thuler LCS, Mendonça GA. Estadiamento inicial dos casos de câncer de mama e colo do útero em mulheres brasileiras. Rev Bras Ginecol Obstet 2005; 27:656-60.

14. Herbert A, Singh N, Smith JA. Adenocarcinoma of the uterine cervix compared with squamous cell carcinoma: a 12-year study in Southampton and South-west Hampshire. Cytopathology 2001; 12:26-36.
15. Leyden WA, Manos MM, Geiger AM, Weinmann S, Mouchawar J, Bischoff K, et al. Cervical cancer in women with comprehensive health care access: attributable factors in the screening process. J Nat Cancer Inst 2005; 97:675-83.

16. Leite FMC, Amorim MHC, Nascimento LGD, Mendonça MRF, Guedes NSA, Tristão KM. Mulheres submetidas à coleta de Papanicolaou: perfil socioeconômico e reprodutivo. Rev Bras Pesqui Saúde 2010; 12:57-62.

17. Ramos AS, Palha PF, Costa Jr. ML, Sant'Anna SC, Lenza NFB. Perfil de mulheres de 40 a 49 anos cadastradas em um núcleo de saúde da família, quanto à realização do exame preventivo de Papanicolaou. Rev Latinoam Enferm 2006; 14:170-4.

18. Peres RS, Santos MA. Câncer de mama, pobreza e saúde mental: resposta emocional à doença em mulheres de camadas populares. Rev Latinoam Enferm 2007; 15:786-91.

19. Schneider IJC. Estudo de sobrevida em mulheres com câncer de mama em Santa Catarina [Dissertação de Mestrado]. Florianópolis: Universidade Federal de Santa Catarina; 2008.

20. Mendonça GAS, Silva AM, Caula WM. Características tumorais e sobrevida de cinco anos em pacientes com câncer de mama admitidas no Instituto Nacional de Câncer, Rio de Janeiro, Brasil. Cad Saúde Pública 2004; 20:1232-9.

21. Hsu JL, Glaser SL, West DW. Racial/ethnic differences in breast cancer survival among San Francisco Bay area women. J Natl Cancer Inst 1997; 89:1311-2.

22. Migowski A, Silva GA. Sobrevida e fatores prognósticos de pacientes com câncer de próstata clinicamente localizado. Rev Saúde Pública 2010; $44: 344-52$

Submitted on 30/May/2012

Final version resubmitted on 12/Nov/2012

Approved on 03/Dec/2012 